\title{
The Textual History of the Qur'an
}

\author{
by Dr Bernie Power
}

A

ccording to most Muslims, the Qur'an has existed forever. It is called the 'mother of the book'(Q.3:7;13:39; 43:4 $)^{1}$ and 'the preserved tablet' (Q.85:21,22) which has always been present beside the throne of Allah. In Muslim understanding, it was revealed or 'sent down' piece by piece to the prophet Muhammad (b.570 CE) via the angel Gabriel during 23 years from $610 \mathrm{CE}$ until his death in $632 \mathrm{CE}$. Muhammad then recited what he heard (since he was illiterate - Q.7:158) to his followers who wrote them down or memorized his sayings. He spoke in the language of the Quraish, one of the current Arabic dialects. At a later stage Muhammad's revelations were all gathered

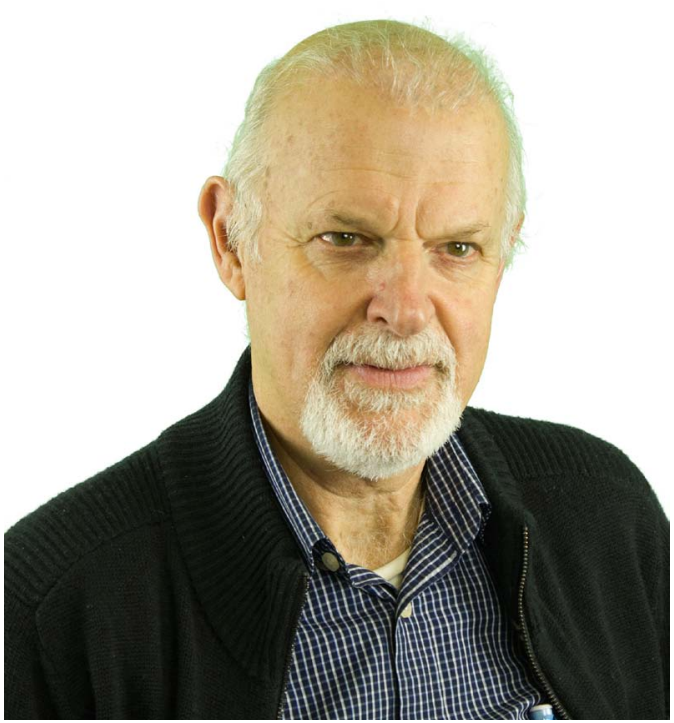
into one book. 20 years later this was edited into a single authorized copy, and that is said to be identical with the present Arabic Qur'an.

Muslims are so confident about this process that they make statements like the following: "So well has it been preserved, both in memory and in writing, that the Arabic text we have today is identical to the text as it was revealed to the Prophet. Not even a single letter has yielded to corruption during the passage of the centuries." ${ }^{2}$ Another publication, widely distributed in Australia, says: "No other book in the world can match the Qur'an ... The astonishing fact about this book of ALLAH is that it has remained unchanged, even to a dot, over the last fourteen hundred years.... No variation of text can be found in it. You can check this for yourself by listening to the recitation of Muslims from different parts of the world." ${ }^{3}$ Muslims consider it to be a miraculous book, both in its contents and its preservation.

However, Islamic sources themselves have raised questions about each of the above steps and the subsequent claims. One Muslim scholar was suspicious about the amount of material in the Qur'an that is common with the Bible. The stories of Old Testament

1 Qur'anic references are shown like this: e.g. Q.3:4 - The Qur'an, Chapter (or Sura) 3, verse 4. The Qur'an can be read online at www.quran.com or www.thequran.com.

2 Abdullah Yusuf Ali The Holy Qur'an: English Translation of the Meanings and Commentary (Madinah: King Fahd Complex for the Printing of the Holy Qur'an, 1413 AH), v.

3 (No author listed) Basic Principles of Islam, Abu Dhabi, UAE: The Zayed Bin Sultan Al Nahayan Charitable \& Humanitarian Foundation, 1996, 4. 
"On one occasion Muhammad heard a voice which he assumed was

Gabriel and recited the verse that he heard. However later Gabriel came to him and told him that those verses came from Satan. The Qur'an comments on this, noting that it was not unusual (Q.22:52). This event inspired the title of the book Satanic Verses by British author Sir Salman Rushdie." and New Testament characters and events (often with different details) make up about 25\% of the Qur'an. Ali Dashti, the former Iranian Foreign Minister said: "For those who consider the Qur'an to be a miracle because of its contents, the difficulty is rather that it contains nothing new in the sense of ideas not already expressed by others. All the moral precepts of the Qur'an are self-evident and generally acknowledged. The stories in it are taken in identical or slightly modified forms from the lore of the Jews and Christians, whose rabbis and monks Mohammad had met and consulted on his journeys to Syria, and from memories conserved by descendants of the [ancient Arab tribes]."

The Qur'an itself admits that Muhammad received revelations from other sources. On one occasion Muhammad heard a voice which he assumed was Gabriel and recited the verse that he heard. However later Gabriel came to him and told him that those verses came from Satan. The Qur'an comments on this, noting that it was not unusual (Q.22:52). This event inspired the title of the book Satanic Verses by British author Sir Salman Rushdie.

Some have suggested that a few of the ideas might have come from the prophet himself. When Muhammad received a revelation permitting him to vary his system of taking turns sleeping with a different wife each night (at that stage he had about ten wives), and even bypassing Sawda, a less-attractive older wife (Q.33:51), Aisha, his child-bride sarcastically commented to him: "I feel that your Lord hastens in fulfilling your wishes and desires." (Hadith alBukhari 6:311)

Muhammad sometimes forgot the verses he had previously received. "The Prophet heard a man (reciting the Qur'an) in the mosque, and he said, "May Allah bestow His Mercy upon him. No doubt, he made me remember such-and-such verses of such-andsuch Sura which I dropped (from my memory)'." (Hadith alBukhari 3:823; $6: 556,557,558,562$ ). He told his followers: "I am a human being like you and liable to forget like you. So if I forget remind me." (Hadith alBukhari 1:394,469)

He was open to receiving advice from others. One time he received a revelation about those who went out to fight in jihad compared with those who stayed at home. He said: "Not equal are those believers who sit (at home) and those who strive and fight in the Cause of Allah." (Q.4.95) However "Amr bin Um Maktum, a blind man was sitting behind the Prophet. He was concerned that he was unable to fight. He said, "O Allah's Apostle! What is your order for me (as regards the above Verse) as I am a blind man?” The Hadith records

\footnotetext{
4 Ali Dashti Twenty Three Years: A Study of the Prophetic Career of Mohammed (London: George Allen and Unwin, 1985), 44.

5 The Hadith are the traditions about Muhammad recorded by his followers.

$\mathrm{Al}-\mathrm{Bukhari}$ is seen by Muslims as the most authentic. These can be accessed online via the website: www.searchtruth.com.
} 


\section{"As the Muslims}

went to fight

at Yamama in

eastern Arabia in

632 CE, just after

Muhammad's

death, many of

those who had

memorized parts

of the Qur'an were

killed in battle.

So the leaders

decided to compile

a complete written

copy. Muhammad

himself had not

done so, so there

was some reticence

to do this." that Muhammad then received a revised version of this revelation. "So Allah revealed to his Apostle ... instead of the above Verse, the following Verse was revealed, "Not equal are those believers who sit (at home) except those who are disabled ....and those who strive and fight in the cause of Allah." (Q.4.95) [Hadith al Bukhari 6:512; also $6: 116,117,118 ; 4: 85]$

As well as his listeners, some of Muhammad's forty-two scribes also contributed to the Qur'an. One of them, 'Abdallah Ibn Sarh al-`Amiri, said: "I used to direct Muhammad wherever I willed. He would dictate to me 'Most High, All-Wise', and I would write down 'All-Wise' only. Then he would say, 'Yes it is all the same'. On a certain occasion he said, 'Write such and such', but I wrote 'Write' only, and he said, 'Write whatever you like."' Abdullah later left Islam due to this. He returned to Christianity again and he used to say: "Muhammad knows nothing but what I have written for him." (Hadith Al-Bukhari 4:814)

Some verses of the Qur'an were lost. The command to stone adulterers, still practised in some Muslim communities today, was previously in the Qur'an. 'Umar, one of Muhammad's fathers-inlaw, said: "We did recite this Verse and understood and memorized it. Allah's Apostle [carried] out the punishment of stoning and so did we after him." (Hadith al-Bukhari 8:817, 816). However this verse is not in today's Qur'ans. Aisha describes what happened to the material on which the stoning verse was written: "its sheet was under my bed; when therefore the Apostle of God died, and we were occupied about his death, a tame animal [a sheep or a goat] came in and ate it."

This was not the only verse that disappeared. Aisha said: "During the time of the Prophet (s) two hundred verses of the chapter al-Abzab [Sura 33] were recited but when compiling the Qur'an 'Uthman was only able to collect what now exists." ${ }^{\prime}$ The current chapter $A l-A b z a b$ now has only 73 verses, so 127 verses have gone missing.

As the Muslims went to fight at Yamama in eastern Arabia in $632 \mathrm{CE}$, just after Muhammad's death, many of those who had memorized parts of the Qur'an were killed in battle. So the leaders decided to compile a complete written copy. Muhammad himself had not done so, so there was some reticence to do this. But Abu Bakr, the first leader after Muhammad, ordered this to happen. Zaid bin Thabit, commissioned to do this, reported that "I started looking

6 Al-Sira by al-'Iraqi, cited in Is the Qur'an Infallible? by 'Abdallah `Abd alFadi, Order Number VB 4009 E, Light of Life, P.O. Box 13, A-9503 Villach, Austria.

7 Quoted in the following six Islamic sources: Ibn Majah, Nikah, 36/1944; Ibn Hanbal, 5/131,132,183; 6/269) Musnad Ahmad bin Hanbal. vol. 6, 269; Sunan Ibn Majah, 626; Ibn Qutbah, Tawil Mukhtalafi '1-Hadith (Cairo: Maktaba alKulliyat al-Azhariyya. 1966) 310; As-Suyuti, ad-Durru '1-Manthur, vol. 2, 13.

8 Al-Suyuti al-iqtan fi ulum al-quran Section: "nasikh and mansukh". 


\section{"In case you}

disagree with Zaid

bin Thabit on any

point in the Qur'an,

then write it in the

dialect of Quraish,

the Qur'an was

revealed in their

tongue." They did

so. All other copies

of the Qur'an

were ordered to be

burned. (alBukhari

6:510, 507) As

we shall see later,

this task was

not carried out

completely." for the Qur'an and collecting it from (what was written on) palm stalks, thin white stones and also from the men who knew it by heart, till I found the last Verse of Surat At-Tauba (Repentance) [Chapter 9 verses 128,129) with Abi Khuzaima Al-Ansari, and I did not find it with anybody other than him." Apparently there was not one person still alive who had memorized the entire Qur'an. It was discovered that "many (of the passages) of the Qur'an that were sent down were known by those who died on the day of Yamama...but they were not known (by those who) survived them, nor were they written down, ... nor were they found with even one (person) after them." ${ }^{10}$

However some other Muslims had their own copies of Muhammad's recitations. "The Qur'an was collected in the lifetime of the Prophet by four (men), all of whom were from the Ansar: Ubai ([Abu Ad-Darda], Muadh bin Jabal, Abu Zaid and Zaid bin Thabit." (alBukhari 5:155; 6:525, 526) These men were from Medina, so they spoke a different dialect of Arabic to Muhammad's Meccan Quraishi dialect. Besides these, there were about twelve other versions of the Qur'an circulating around that had been collated by this time, including those by 'Abdullah ibn Mas'ud and Abu Musa al Ash'ari. These versions were dispersed throughout the now-growing Muslim empire, and some gained greater popularity in particular geographical locations.

In around $650 \mathrm{CE}$, a group of Muslim soldiers from Syria and Iraq, were preparing to invade Armenia. They were in a mosque near Azerbaijan waiting to listen to the Qur'an being read. An official called out, 'Those who follow the reading of Abu Musa [al Ash'ari], go to the corner nearest the Kinda door. Those who follow 'Abdullah's [ibn Mas'ud] reading, go the corner nearest 'Abdullah's house.'Their reading of Q 2.196 did not agree." ${ }^{11}$ An argument broke out between these groups about which was the correct reading. One of their leaders, Hufaida, returned to Mecca and asked the Caliph, Uthman bin 'Affan, to sort this problem out.

The Caliph asked for the earlier compiled copy and appointed a committee of four to produce a single authorized version. 'Uthman then ordered Zaid bin Thabit, 'Abdullah bin AzZubair, Said bin Al-As and 'Abdur-Rahman bin Harith bin Hisham to rewrite the manuscripts in perfect copies. 'Uthman said to the three Quraishi men, "In case you disagree with Zaid bin Thabit on any point in the Qur'an, then write it in the dialect of Quraish, the Qur'an was revealed in their tongue."They did so. All other copies of the Qur'an were ordered to be burned. (alBukhari 6:510, 507) As we shall see later, this task was not carried out completely.

Even this authorized copy was not perfect. "When the first copy

9 alBukhari 6:509.

10 Ibn Abi Dawud, Kitab al-Masahif, 23.

11 Abu Bakr `Abdullah b. abi Da’ud, “K. al Masahif”, ed. A. Jeffery, Cairo, 1936/1355, 11. 
of the Qur'an was written out and presented to [the khalif] Othman Ibn Affan, he said: 'There are faults of language in it, and let the Arabs of the desert rectify them with their tongues." ${ }^{2}$

It was also recognised that this version was not complete. Ibn Umar, the son of the second Caliph, said: "Let none of you say 'I have acquired the whole of the Qur'an'. How does he know what all of it is when much of the Qur'an has disappeared? Rather let him say 'I have acquired what has survived'."13

However some of the other versions survived, or are quoted in other sources. There are books which give details of the differences from the authorized Uthman version. In $987 \mathrm{CE}$, seven books describing these differences were listed by a Muslim writer: ${ }^{14}$

1) The Discrepancies between the Manuscripts of the People of al-Madinah, al-Kufah, and alBasra according to al-Kisa'i

2) Book of Khalaf, Discrepancies of the Manuscripts

3) Discrepancies of the People of al-Kufah, al-Basrah, and Syria concerning the Manuscripts, by al-Farra

4) Discrepancies between the Manuscripts by Abu Da'ud al-Sijistani

5) Book of al-Mada' ini about the discrepancies between the manuscripts and the compiling of the Qur'an

6) Discrepancies between the Manuscripts of Syria, al-Hijaz, and al-Iraq, by Ibn'Amir alYahsubi

7) Book of Muhammad ibn 'Abd al-Rahman al-Isbahani about discrepancies of the manuscripts.

These differences have persevered, and there are 33 different Arabic Qur'anic texts in existence today. They are:

\begin{tabular}{|l|l|l|l|}
\hline 1. Qaloon & 9. Al-Susi (Ibn Katheer) & 17. Khallad & 25. Idrees \\
\hline 2. Warsh & $\begin{array}{l}\text { 10. Hafs Ad-Duri (Abu } \\
\text { Amro alBasri) }\end{array}$ & 18. Al-Laith & 26. al-Bazzi \\
\hline 3. Al-Azraq & $\begin{array}{l}\text { 11. As-Susi (Abu } \\
\text { Amro alBasri) }\end{array}$ & 19. Ad-Duri (alKisa'i) & 27. Ibn Shanboodh \\
\hline 4. Al-Asbahaani & 12. Hisham & 20. Isa BinWardan & 28. Sulayman \\
\hline 5. al-Bazzi & 13. Ibn Dhakwan & 21. Ibn Jammaz & 29. Ahmad bin Farah \\
\hline 6. Qunbul & 14. Showba & 22. Ruwais & $\begin{array}{l}\text { 30. Shujaa' bin Abi Nasr } \\
\text { Al-Balakhi }\end{array}$ \\
\hline 7. Abu Amro Al-Ala & 15. Hafs & 23. Ruh & $\begin{array}{l}\text { 31. Al-Duri (alHasan } \\
\text { alBasri) }\end{array}$ \\
\hline $\begin{array}{l}\text { 8. Hafs Al-Duri (Ibn } \\
\text { Katheer) }\end{array}$ & 16. Khalf & 24. Ishaq & $\begin{array}{l}\text { 32. Al-Hasan bin Said } \\
\text { Al-Matuu'i }\end{array}$ \\
\hline & & & $\begin{array}{l}\text { 33. Abu Farah Al-Shan- } \\
\text { budhi }\end{array}$ \\
\cline { 2 - 3 }
\end{tabular}

Many of these can still be bought in bookstores around the Middle East and even online. ${ }^{15}$ This author has collected 16 of the above Arabic versions.

12 (Wafayat al-Ayan (The Obituaries of Eminent Men) also known as The Biographical Dictionary, Abu-1 'Abbas Ahmad Ibn Khallikan,) 401.

13 as-Suyuti, Al-Itqan fii Ulum al-Qur'an, 'Perfection in Qur'anic sciences'), 524.

14 al-Nadim The Fihrist of al-Nadim - A Tenth Century survey of Muslim Culture Bayard Dodge (ed.)(New York: Columbia University Press, 1970), 79.

$15 \mathrm{http} / /$ www.easyquranstore.com/tajweed-quran-in-other-narrations-rewayat/. 
These versions have arisen due to a defect in the earliest Qur'ans. The original Arabic script had no vowels, and lacked the dots, which distinguish half of its 28 consonants. A single dot under a letter makes it a 'b' whereas a dot above makes it an ' $n$ '. Two dots below make it a ' $y$ ' or long 'i', and two dots above make it a ' $t$ ', and so on. One three-letter word, the simplest orthographic structure, can have up to 30 different meanings, depending on where the dots and vowels are placed. The undotted and unvowelled text could only be read by someone who already knew what it said.

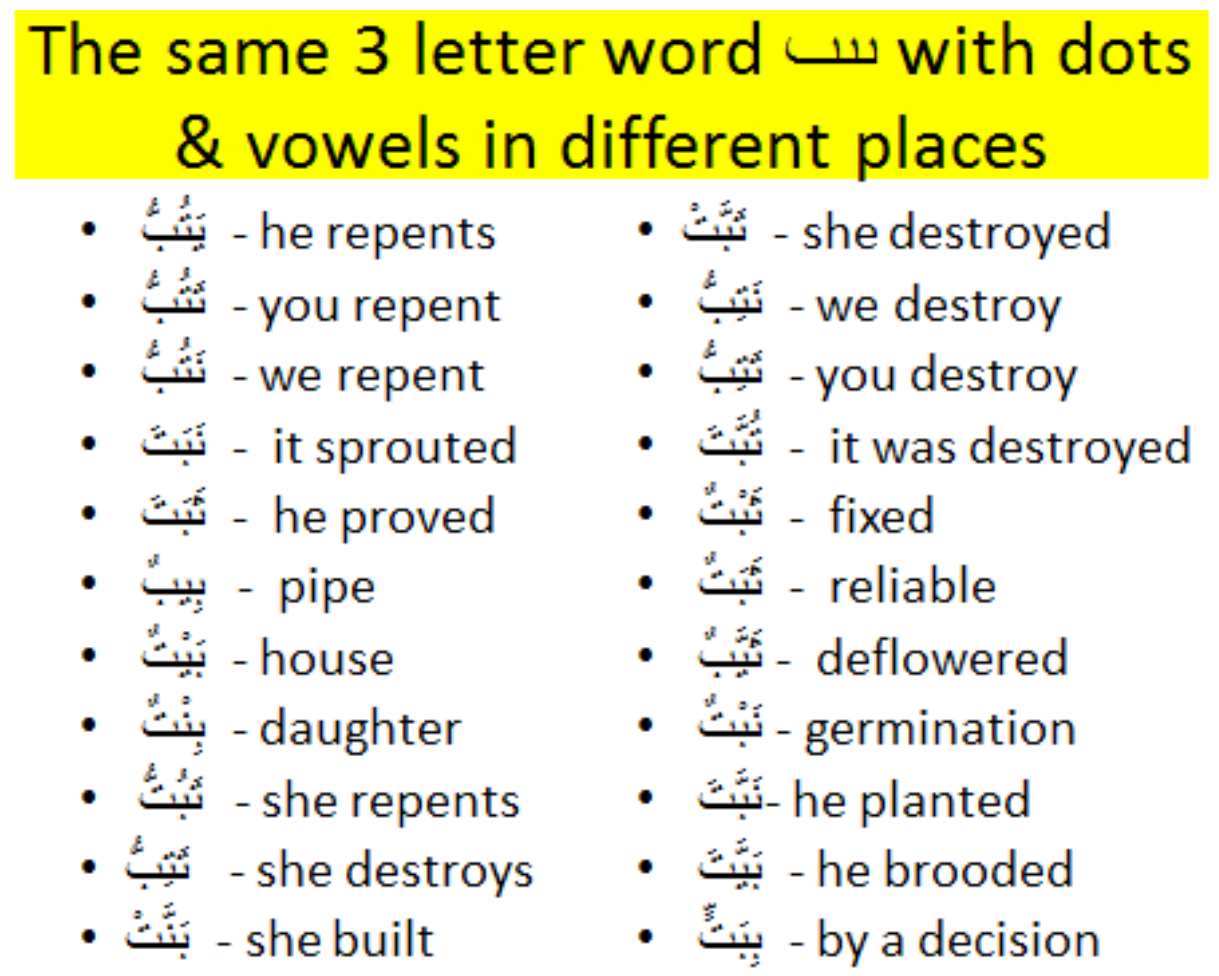

As Islam spread to new countries where Arabic was not the native tongue, these texts were dotted and vowelled in different ways, leading to the 33 variant texts which we have today. Why can't these be compared with the original text to determine which is the correct version? According to Muslim convert and scholar, Professor Annemarie Schimmel: "No original Qur'anic text has survived." 16

A Turkish researcher stated that "[u]nfortunately there is no reliable information about the first Mushafs [texts of the Qur'an] which were apparently destroyed or disappeared as a result of incidents and natural disasters such as wars and fires. This has been one of the greatest weaknesses and pains of the Islamic world throughout the history." ${ }^{17}$

In 1972, a major discovery was made in the Great Mosque, in Sana'a, Yemen. Sandwiched between two walls were 40,000 old manuscripts. Study by German scholars has revealed them to be the texts of nearly 1000 ancient Qur'ans, dated in the mid to late $7^{\text {th }}$ century, making them the earliest copies of the Qur'an in existence. Amongst them was a parchment (animal skin) with Qur'anic verses, some of which had been modified. A closer inspection showed that this was a palimpsest - an earlier version of the Qur'an had previously been written on this parchment and either worn off or washed away. However, multispectral imaging could read the traces of ink left behind, revealing a text which had also been

16 Anne-Marie Schimmel Calligraphy and Islamic Culture (New York: New York University Press, 1984), 4.

17 Dr. Tayyar Altikulac (ed.) Al-Mushaf Al-Sharif, (Istanbul, IRCICA, 2009), 36-37. 
"The task of

discovering the

original Arabic

words of the Qur'an

as dictated by

Muhammad to

his followers will

continue as scholars

do this important

work." modified. This one parchment showed that this Qur'an had existed in four editions - two on the earlier and lower text, and two on the upper text. Each of these show significant variations from the texts found in today's Qur'ans. Some words and phrases found in today's texts are missing, and phrases and words in these Sana'a texts are not present in modern Qur'ans. Different words (often synonyms) are found in the earlier texts, and words or sentences have been moved around. It is clear that the Qur'an was going through an editorial process in this period.

The Canadian scholar Professor Andrew Rippin noted: "These manuscripts say that the early history of the Koranic text is much more of an open question than many have suspected: the text was less stable, and therefore had less authority, than has always been claimed." ${ }^{18}$

The task of discovering the original Arabic words of the Qur'an as dictated by Muhammad to his followers will continue as scholars do this important work.

A PowerPoint presentation to accompany this paper can be found as a Supplementary file (on the right-hand-side under Reading Tools).

\section{References}

Abdullah, Yusuf Ali. The Holy Qur'an: English Translation of the Meaning and Commentary. Madinah: King Fahd Complex for the Printing sof the Holy Qur'an, 1413.

Ali, Dashti. Twenty Three Years: A Study of the Prophetic Career of Mohammed. London: George Allen \& Unwin, 1985.

Basic Principles of Islam. UAE: The Zayed Bin Sultan Al Nahayan Charitable \& Humanitarian Foundation, 1996.

“The Noble Qur'an - ميركلانآرقل." http://quran.com/.

"Search Engine: Search in the Quran نارقل קيرك and Muslims. Islamic Softwares, Azan, Athan, Qiblah, Prayer Times, Quran Hadith, Islamic Supplictaions, Azan Athan Software for Mobile Cell Phone." http://www.searchtruth.com/. 